\title{
The Phenomenon of Digital Art as a Means of Preservation of Cultural Heritage Works
}

\author{
Svitlana Kryvuts - Olena Gonchar - Alina Skorokhodova - Mykola Radomskyi
}

As. Prof. Svitlana Kryvuts PhD,

Faculty of Environment Design

Kharkov State Academy of Design and Arts

Vul. Mystetstv, 8

61002 Kharkiv

Ukraine

e-mail: svkdesignsvk@gmail.com

Prof. Olena Gonchar PhD,

Vice-Rector for Research and International relations

Kharkov State Academy Culture

Bursatskyi uzviz,4

61057 Kharkiv

Ukraine

e-mail: helengo2006@gmail.com

As. Prof. Alina Skorokhodova PhD,

Faculty Design of Architectural Environment

National University of Construction and Architecture

Vul. Sumska, 40

61002 Kharkiv

Ukraine

e-mail: alinask1106@ukr.net

As. Prof. Mykola Radomskyi PhD,

Faculty of Environment Design

Kharkov State Academy of Design and Arts

Vul. Mystetstv, 8

61002 Kharkiv

Ukraine

e-mail: radomskynikolai@gmail.com

The Phenomenon of Digital Art as a Means of Preservation of Cultural Heritage Works

The constant development of multimedia technologies and, as a result, their rapid spread among countries around the world has been a general trend in digital art in the late twentieth and early twenty-first century. This phenomenon, as practice shows, comes out top among other creative activities. With the help of multimedia technologies it is possible to optimize multimedia systems in figurative and meaningful value relations. An important role here is given to the development of a unigue multimedia "language", which harmoniously combines technical, creative and value-oriented components.

This article presents an analysis of the use of the submersive method in solving scenario-design problems for the preservation of elements of cultural heritage through the use of $3 \mathrm{D}$ mapping and video projection in exhibition space design and for projections onto the facades of architectural landmarks. The content of such video projections and specific characteristics of the artistic images they draw upon depend on the functional purpose of the context in which the interactive work is presented. There remains a need for greater scientific understanding of the phenomenon of interactive art, in the interests of improving professional design practices in the preservation of cultural heritage works.

Keywords: interactive art, submersive method, exhibition space, design, cultural heritage. 
Since the beginning of the twenty-first century, interactive technologies have had a decisive influence on the dissemination of information, the transmission of events by artistic and computer-based means, the reproduction of cultural values and the creation of new spectacular scenarios that reflect historical and cultural events. Solving this problem from the standpoint of the evolution of creative approaches to the disclosure of exhibition material by various means has occupied many scientists. Paul Basu and Sharon MacDonald were actively involved in the problem of defining transformational processes in the formation of the information field of the museum space ${ }^{1}$. The authors emphasize that despite the diversity of the authors' professional experience and the contexts of the exhibitions they write about, there was an extraordinary sequence of arguments and observations in many aspects of their work. The idea of the growing dissemination of the exhibition experiment as attracting the visibility of the exhibition processes themselves is relevant in terms of coverage of experimental interactive concepts. The intensification of the introduction of digital technologies, of course, contributed to the mass spread of interactivity in the creation of exhibition and museum space, as evidenced by a study by Irida Ntalla. Interactive technologies, according to Irida Ntalla, will help improve visitor communication, direct him to active participation within the exhibition space and engage in social interaction ${ }^{2}$. The multifunctionality of $3 \mathrm{D}$ video projections - that is, artistic images designed specifically for projection onto a contoured background such as an architectural landmark - and their development both as a means of communication and as works of art, has led to the identification of specific ways to reflect reality and helped to create a "universal" language of design solutions. Rapidly evolving, interactive technologies have intensified the search for new visual means of forming the emotional climate of socio-cultural space through new techniques and ways of synthesizing architectural and natural elements of the urban environment using virtual technologies. The process of forming such syntheses is complex and involves both architecture and design.

In addition, one of the main tasks of today is the digitization of cultural heritage, the use of works of art by means of virtual reality, the creation of cyberspace, modeling projections of $2 \mathrm{D}$ and 3D images. All these concepts affect the development of new directions in the humanities, especially in the field of art education, and help to solve important problems of preserving world cultural heritage in the form of virtual tours ${ }^{3}$. An important factor is the presence of the theoretical justification of techniques and the means of taskling the design of special effects in multimedia art. Researcher A.-V. Kerlow describes the fundamental aspects of creating three-dimensional animation, which include modeling, visualization and the realisation of digital works. He shows the directions in which design concepts are implemented in practice, taking into account various techniques ${ }^{4}$. S. Kryvuts' work defines the system-forming factors

\footnotetext{
${ }^{1}$ BASU, Paul and MACDONALD, Sharon. Introduction: Experiments in Exhibition, Ethnography, Art and Science. In: Basu \& Macdonald (eds.), Exhibition Experiments. Oxford: Blackwell Publishing, 2007.

${ }^{2}$ NTALLA, Irida. Interactivity and audience experience in the modern museum. In: E. Kristiansen (ed.), Proceedings of the Dream Conference. Roskilde University, Denmark, 2012, pp. 252-266.

3 ŽUPČÁNOVÁ, Martina and ŽUPČÁN, Ladislav, Kyberpriestor ako moderná forma komunikácie. In: Mediálna seba prežentácia a budovanie individuálneho imiď̃u múzea, 21, 2014, p. 82.

${ }^{4}$ KERLOW, Isaac V. The Art of 3D Computer Animation and Effects. Wiley, 2009, p. 512.
} 
which "... promote revealing of mechanisms of self-regulation within system of exposure" .

These should include: 1) elements that determine which parts make up the system itself; 2) the form by which the degree of harmony is revealed; 3) a function that makes it possible to identify the nature of the system as a whole; 4) content that expresses its concept, meaning and purpose. Problems relating to the interconnections between information and communication environments, multimedia design and modern societal culture are considered by researcher $\mathrm{O}$. Shlykova. At all stages in the formation of the artistic image of a 3D-projection, the authors creates the image through the prism of feelings, thoughts, preferences and professional experience. The creation of interactive works of art is based upon the dynamics of their installation, freedom in the composition of the material and the aesthetic significance of each element arising from the professional movement of the camera or change of focus. As for the specific expressive accents, they are provided by the combination of reality and game that is characteristic of 3D projections: the observance of balance in their combination makes the image meaningful. That is, the general concept of 3D-image is of an artistic image-work that has a certain influence on the formation of the audience's impression.

The role of modern 3D video design in society is huge, because video projections perform several important functions: they can be informative, emotional-entertaining, semiotic (symbolic), translational and a function of the aestheticization of both personal and social spiritual space. The weight of the above functions is analyzed in the paper "Cyberspace as a modern form of communication" ". The authors emphasize that important steps in the future include is not only ensuring easy access to digital collections, but also bringing about a meaningful change in the services offered by providing the exhibition with more detailed accompanying texts, interpretive or educational interactive presentations. Only in this way, will the virtual exhibition be of real benefit to the general public, and not only for researchers and students. L. Kesner deals with the problem of the quality of visual perception of the proposed exposition material ${ }^{7}$. Observing that modern people are oversaturated with visual stimuli. Given this, attention should be paid to the quality of museum exhibits. The main responsibility should be the professionalism of interactive information services.

Therefore, it is advisable to explore the possibilities of experimental design developments that reveal the content of the exhibition material by artistic means, taking into account the above functions. In addition, it should be noted that the techniques of creating artistic images on the basis of hyperbolization fill the modern visual space with effective and vivid artistic-graphic, informational projections. Hyperbolization enhances the impact of the underlying meaning of video images on the viewer from the beginning. The main tool here is a large number of special effects, built on visual illusions that make the viewer believe in the created video projection. Thus, with the help of optical illusions, designers try to build a new reality, to discover a new structure of things, thanks to which it is possible to emphasize the expressiveness and

${ }^{5}$ KRYVUTS, Svitlana and GONCHAR, Olena. Polyfunctionality of 3D videomapping as a new structural model of communicative influence in a design environment. In: Aktuelle Themen im Kontext der Entwicklung der modernen Wissenschaften: der Sammlung wissenschaftlicher Arbeiten " $\Lambda$ 'OГO $\Sigma$ ” zu den Materialien der internationalen wissenschaftlich-praktischen Konferenz, Dresden, 23 January, NGO “Europäische Wissenschaftsplattform”. Vol. 6. pp. 17-19; see also KRIVUTS, S.V. (2015). The role of media design in the formation of the exhibition space. In: Danilenko (ed.) Bulletin of the Kharkiv State Academy of Design and Arts: Collection of scientific works, V.Ya. Kh.:KSADA, p. 36-41.

${ }^{6}$ ŽUPČÁNOVÁ, Martina and ŽUPČÁN, Ladislav. Kyberpriestor ako moderná forma komunikácie. In: Mediálna seba prežentácia a budovanie individuálneho imiď̃u múzea, 21, 2014, p. 82.

${ }^{7}$ KESNER, Ladislav. Muz̨um umèni v digitálni dobè: Vnimáni obraži a prožitek umèní v soudobé společnosti. Praha: Argo a Národní galerie v Praze, 2000.. 
informativeness of the environment. As the visual material of some of the spectacular interactive works of art that already exist show, designers use various means of figurative expression, among them:

- reception of colour contrast;

- reception of optical illusions;

- geometric patterns in the form of lines, points, spirals;

- compositions of constantly moving parts.

It should be noted that the visually contradictory configuration of the elements creates a conflict between the actual shape of the architectural object and the shape that can be seen in the video image. Thus, the illusion is created of spatial movement, expansion and merging of forms with the help of colour and tonal contrasts, rhythmic repetitions and intersection of spiral configurations and lines. In addition, 3D video projections can be built that create an interactive show with the participation of viewers. This innovative approach exploits the possibility of 3D-projections to react to the movements of the spectators, involving everyone in the game by means of interactive video control. First of all, there is the effect of presence-involvement, which arises from the great power of involving the viewer in the constructed image design through something that actually happens to the viewer and that has personal significance for him or her. The effect of presence-involvement can virtually unite a huge audience, giving a sense of unity and contributing to a certain form of empathy.

In the creation of interactive works, the function of aestheticization of both personal and social spiritual space is the ability by means of a 3D display to join aesthetic ideas and norms, the ability to shape a person's own aesthetic demand and, due to this demand, to develop an active social position.

It should be noted that the translation function is becoming increasingly popular among modern viewers, because it helps to reveal the boundaries of knowledge and cultural information through the use of virtual reality. The digital art of video projection, where 3D images create the illusion of multidimensional movement through the contours of any surface or around these contours, is becoming widespread. By incorporating this ambitious form of technological art, almost any story can be told using the content of a historical, cultural or mythical event.

In today's conditions, modern digital technologies allow the prolongation of the life of any work of art, especially in the case of a museum exhibition or exhibition space. Video projections can most quickly respond to contemporary problems, attract new visitors, expand the range of exposure. The use of interactive technologies to convey the concept of an exhibition is of great interest to professional designers, curators and exhibition organizers. The information function, in this case, involves the development of $3 \mathrm{D}$ - human visual culture, which contains a set of qualities aimed at the aesthetic perception of reality and art. In addition, the ability to record and transmit 3D processes in the dynamics only confirms the ability to convey emotional impact, which is widely used to address the educational function, which involves the dissemination of knowledge, skills and ethical norms required of modern person.

The organization of the architectural space design and its author's concept are created with the expectation that the spectators should feel as comfortable as possible on the one hand, and experience the new, the unknown on the other. The concept of forming an interactive work of art provides for the possibility of a consistent and effective "reconstruction" of the original image, which through certain temporal dimensions controlled by the designer, may be manifested through the following characteristics: 
- incompleteness, an unspoken plot line;

- the relative destructiveness of composite image presentation;

- transformation of the overall composition of video images;

- the openness of the structure of the architectural space to dialogue with the viewer.

A striking example of the above is the multimedia exhibition "Avant-guard. Space of colours and shapes ", an exhibition on the avant-garde which took place in 2014 at the ART Mall shopping and entertainment centre in Kyiv, Ukraine. Episodes of images in the multimedia performance revealed the art of the avant-garde in all its variety of colours, genres and directions. Works by prominent avant-garde artists such as Amedeo Modigliani, Vasyl Kandinsky and Kazimir Malevich were presented at the exhibition, in a bespoke video projection designed to be projected on the walls of the gallery by means of A-Sense technology (Fig. 1-2). The author of the project created an individual artistic space through the preservation of authentic cultural codes. The main concept is the reproduction of cultural heritage traditions by means of modern visual culture.

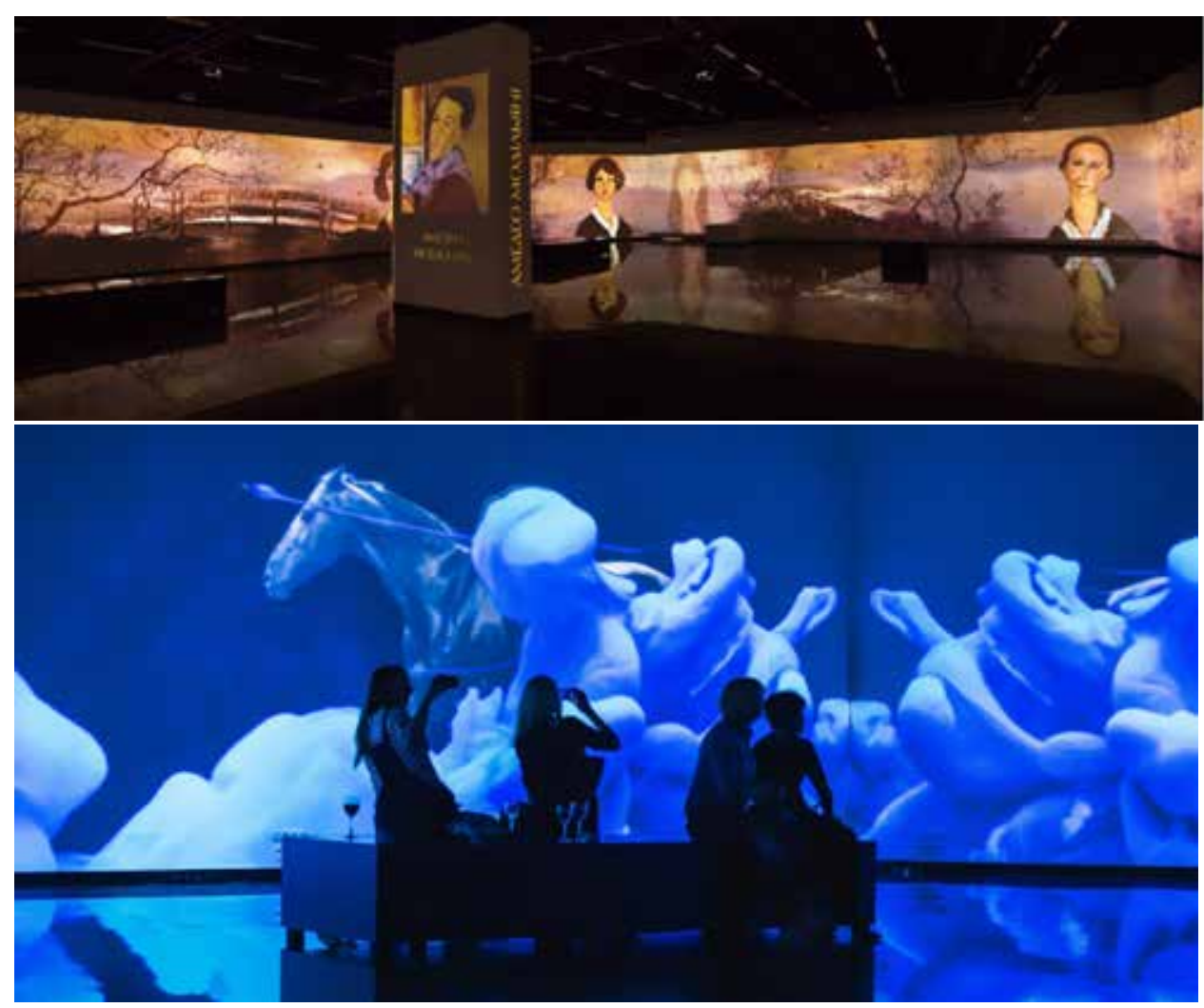

Fig.1. a and b: Exbibition "Avant-garde. Space of colours and shapes", ART Mall shopping and entertainment center, Kyiv (2014).

The gallery was a huge $200 \mathrm{~m}$ long multimedia space whose walls were entirely formed of screens. With the help of 52 projectors, the necessary dynamic high-resolution images of paintings by prominent avant-garde artists were displayed. A powerful server synchronized the sound. The innovative creative characteristics, in this case, lay in the ability to reproduce flat paintings in full three-dimensional volume. When forming video projections, light from the 
images of the characters of the paintings is easily perceived. Thanks to the accurate transfer of colours and shapes and the effects of light and sound, visitors are surrounded by an atmosphere of complete immersion in the space of the exhibition.

The method of immersion, sometimes called submersion, centres on the effect of being completely immersed in the atmosphere of the era or event being depicted; it is used in the design of an artistic image that includes the viewer's imagination and invites It can be used to express the meaningful scenario of an exhibition exposition by incorporating the spectator into the integrity of the exhibition space. The author's idea is aimed at awakening the live interest of the viewer, to manifest his or her personal experience from the interactive show. It is this orientation of the viewer to the plot of the exhibition and his or her complete immersion within it that distinguishes the submersive method from others approaches. A cognitive interactive story about the characteristics of styles and directions of avant-garde art was presented at the multimedia exhibition, by means of music namely (interpretations of famous classical works, light jazz and modern dynamic compositions) to allow viewers to navigate what was happening on the screens, as well as contribute to the formation of stable value-oriented components.

Given the realities of today, it can be noted that the role of media design as a phenomenon of modern culture is actively growing. Rapid changes in this direction allow us to identify ways to optimize its growth. As shown by the material of the developed project proposals, in addition to the above components, the criteria for evaluating multimedia art in the exhibition system are: script, multimedia communication language, interface, functionality and ergonomics (usability). The system-forming factor plays an important role in shaping the design of the exhibition space with the use of interactive technologies. It affects the quality of interaction in the system "personality - society - culture".
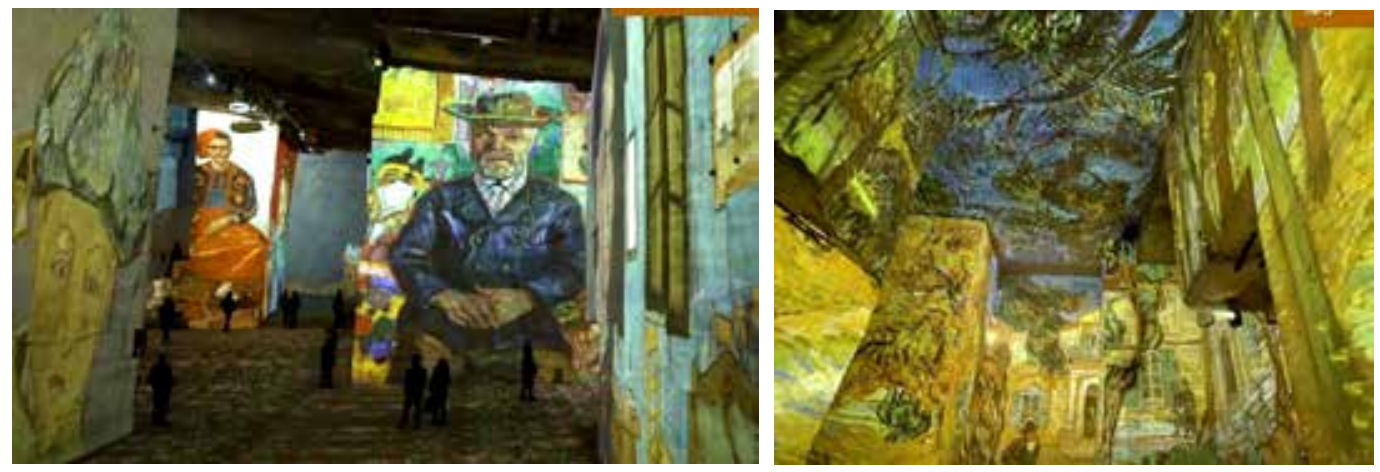

Fig. 2: Exbibition of works by Vincent van Gogh: Center for Digital Art L'Atelier des Lumièresthis, Paris (2019). ${ }^{8}$

It should be noted that in the process of creating a design of 3D images, designers seek to enhance the perception of video projections and encourage the viewer to take the necessary action. In this case, the creation of images is solved on the basis of hyperbolization. This technique is actively used by designers from around the world, filling the modern exhibition multimedia space with effective and bright artistic and graphic, informational projections. The technique of hyperbolization enhances the impact of the underlying meaning of video images on the viewer from the outset. In addition, the hyperbolization of video images is characterized by a significant reduction or increase in the size of the desired shape and the number of its parts (Fig. 2).

${ }^{8}$ Accessed March 13, 2020, https://www.carrieres-lumieres.com/en/van-gogh-starry-night [13.3.2020] 
Video projections create amazing optical illusions through the play of light and help to expand the possibilities for transforming the exhibition space chosen for the design. Thus, we can note the system-forming factors inherent in media design, which contribute to the identification of mechanisms of self-regulation within the exposure system. These include:

- elements that determine which parts create the system itself;

- the form by which the degree of harmony of images is revealed;

- a function that makes it possible to identify the nature of the system as a whole;

- content that reveals the concept of artistic multimedia work;

- submersion method, which determines the degree of immersion in the interactive world of the video projections.

The authors of the project, possessing professional-level means of artistic expression, harmoniously combine the presentation of static and dynamic information. The ability to work within the compositional parameters of space and time allow exhibition designers to play with the rhythm and pace of the story in a multimedia virtual environment. This approach is typical of interactive art, where the temporal component is more compressed and its speed is many times greater than in reality. The combination of text, graphic language, animation and music - with the help of interactive audio-visual technologies that have the maximum impact on the visitor - contributes to a breadth of coverage that can appeal to a wide variety of target audiences. As a result, the design of the exhibition space, created by means of interactive technologies, is designed to connect all these multifaceted and highly specialized components into a single whole, functionally and compositionally. It is modern interactive technologies that determine the nature and direction of today's mass communications. The influence of digital art affects the processes of translation of cultural values and the task of preserving the works of great masters of the past and present.

The project practice of today's famous masters has shown that in the context of globalization, many professionals and finding design solutions for the visualization of abstract, fantasy-based or realistic artistic concepts and images. The media design of the exhibition space allows the creation of interactive multimedia complexes, spectacular exhibits and interview films. Such exhibitions are full of information for visitors of different educational levels and take a modern approach which, if submersive design methods are used, surrounds visitors in the world of digital art, allowing them to travel in the time through dimensions of the past and present. At the same time, interactivity, which is a unique feature of multimedia technologies, fundamentally changes the viewer's perception of the internal or external space of objects.

It should be noted that among the main digital technologies a significant place is occupied by $3 \mathrm{D}$ video mapping. It has become a powerful artistic means of reproducing high-quality animations that transform the image of real architecture into a dynamic virtual 3D environment. Today, thanks to this technology, designers have the opportunity to work on images that can be both simple-abstract and complex-modulated. Masters in this field modulate the design of 3D video mapping, which has its own individual image, using the following approaches: the contextual approach and the ironic-game approach.

Let us consider them more carefully. The contextual approach is based on the interaction of the natural context with architectural or landscape objects and takes into account the following indicators:

- Spatial openness. This indicator allows the designer to explore the most important characteristics of the natural or architectural object through $3 \mathrm{D}$ video mapping using the 
techniques of transformation, modularity and cyclicity (Fig. 3-4). In the examples below, the multimedia video sequence designed to be projected onto the facades of landmark architecture is created as several separate images that enable a stereo effect.
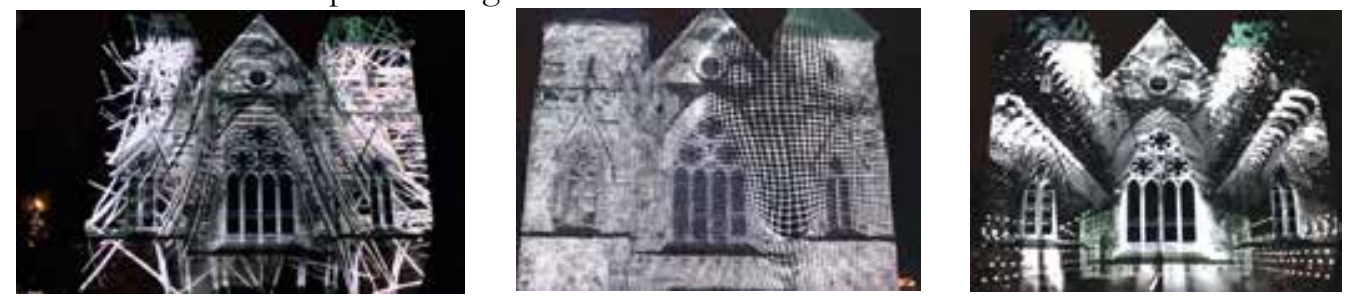

Fig. 3: Techniques of transformation, modularity, cyclicity in 3D video mapping design. BORDOS. ARTWORKS at Screen City Festival 2013, Stavanger, Norway. ${ }^{9}$
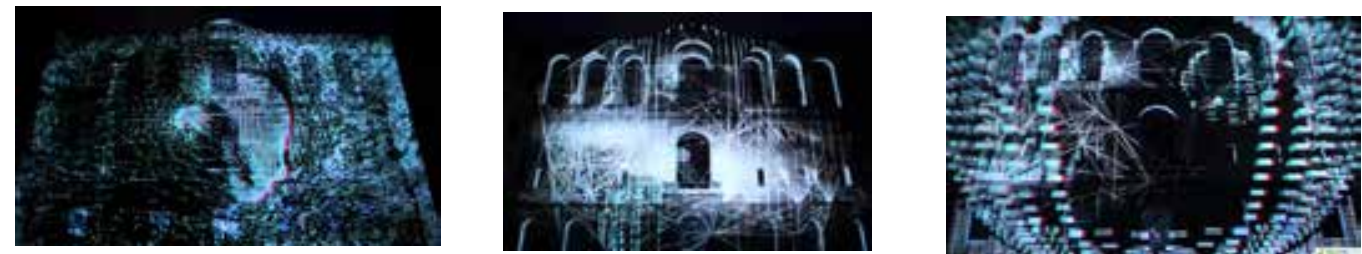

Fig. 4: Techniques of transformation, modularity and cyclicity in 3D video mapping design. Stereo $3 d$ mapping at Mapping Festival 2012, Geneva (Museum of Art and History). ${ }^{10}$

- Historical context. The nature of the design concept of $3 \mathrm{D}$ video projection is influenced not only by the present, but also by important events of past years. The composition of the 3D image has its own features associated with the geographical, ethno-cultural and other characteristics of the region in which they are created (Fig. 5).
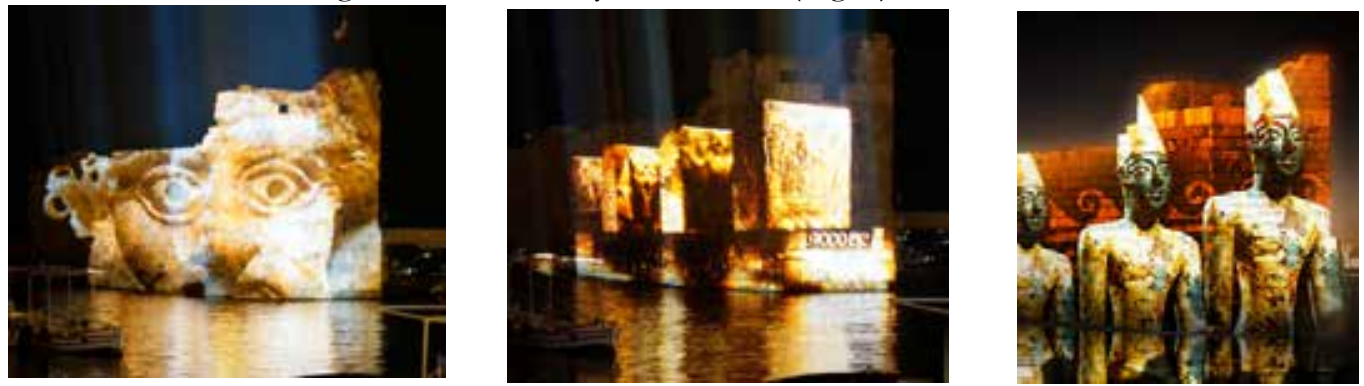

Fig.5. BYBLOS 3D Project Mapping on the water, Byblos-Jibail, Lebanon. ${ }^{11}$

A striking example of water video is the BYBLOS 3D Projection Mapping event celebrating the 8000-year history of Byblos-Jibail, a UNESCO World Heritage Site and one of the oldest cities in the world. The 3D-project was intended both to have a positive impact on tourism and to showcase contemporary technological innovations. The design, by Studio Mr. White and Minus5 Architects, gave central importance to the architectural heritage of Byblos, choosing the medieval fortress in the centre of the old port as a medium on which to project specially offer designed 3D video above the water's surface. The narrative concept of the design focused on expressing each historical period of the city, with historical events depicted in such a way as to

\footnotetext{
${ }^{9}$ Screenshots from video, accessed at https://www.youtube.com/watch?v=thCAi3AXBP8, accessed March 13, 2020 .

${ }^{10}$ Accessed March 13, 2020, https://www.youtube.com/watch?v=n36cpSmKt1c

${ }^{11}$ Accessed March 13, 2020, https://studiomrwhite.com/8000-years-old-city-celebrates-heritage-and-future/
} 
reveal visually the essence of those times. The flow of plot sequences presented viewers with a series of unexpected visual multimedia compositions while maintaining interest throughout the show.

- Cultural context. The main result of this indicator is the ability to reveal the content of socio-cultural reality through the creation of an artistic image of the environment. This task affects the public consciousness of both the designers and the viewer. That is, there is an opportunity to form a common sign system that helps to enter into a dialogue with the viewer (Fig. 6).

Among the masters who pursue continue the theme of how generations connect through historical works of art, it is worth mentioning artist Paolo Buroni, who designs images for projection onto the facades of architectural landmarks in the city squares. He undertakes commissions for events such as the Venice Biennale and has created 3D video mapping for the cities of Budapest, Istanbul, Paris and Seoul. The main idea behind Buroni's work is the use of three spatial dimensions in the interaction between the projected images and the surface of architectural structures. In his video projections, building facades become an integral part of the creative event. Using ancient facades, the artist reveals the content of cultural events, directing the attention of the audience by means of immersive technigues. For example, his annual interactive performance in Piazza di Fabriano, which now in its fifth year, has become a cultural spectacle on an international scale.

The general concept behind the author's 3D images is the creation of an image-work that influences the formation of the audience's impressions and, if necessary, induces participants to engage in certain actions according to a narrative script (Fig. 6). Using collage techniques to create 3D projections from fragments of images, Buroni develops compositions from the paintings of historical masters, reworking them to present new forms and encourage fresh individual perceptions of the historical object. Paolo Buroni calls his work "arte visual", reminiscent of a trip around the world through the past achievements of the works of great masters.
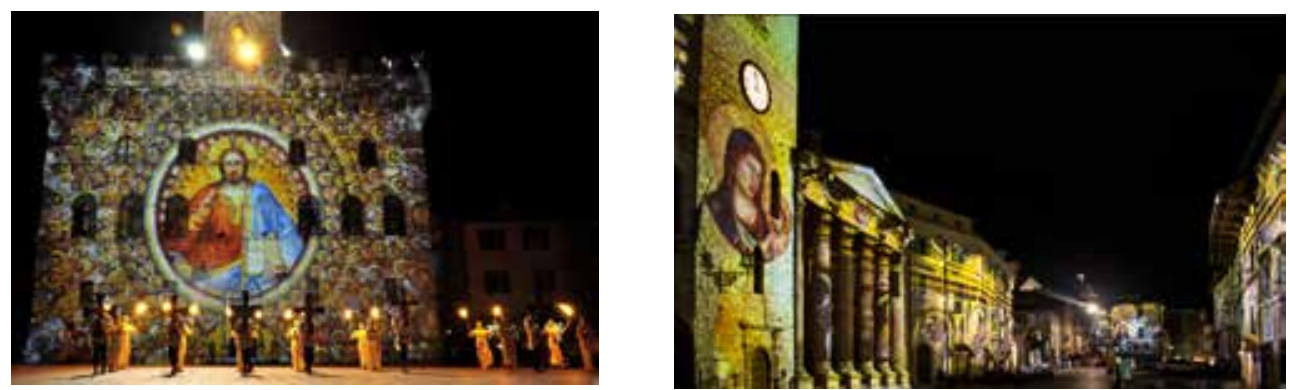

Fig.6. Interactive performance in Piazza di Fabriano, artist Paolo Buroni.12

It should be noted that the author of the project creates his composition in such a way that the viewer perceives the design of $3 \mathrm{D}$ images on the surface of buildings not only in space but also in time, in motion. To see the video images, viewers need to move, to walk around the building, constantly experiencing angles, changing points of view and unexpected expressive images of cultural and historical content. Buroni, through the alternation of pictures, virtually "paints" the route along which spectator move, at the same time permitting their relative free-

${ }_{12}$ Accessed March 13, 2020, http://www.stark1200.com/public/uploads/proiezione_di_immagini_di_grandi_dimensioni.jpg, http://www.stark1200.com/public/uploads/1513012064.jpg 
dom and presenting them with unexpected emotional discoveries. Moreover, the author forms projections of images by planar plans which change interactively.

Among Paolo Buroni's latest innovations are the interactive video images at the Diocesan Museum of Venice (2017), near St. Mark's Square, in which he combines video projection, a 3-dimensional soundscape and olfactory effects to present the famous figure of Venetian musician Antonio Vivaldi. Buroni's design concept represents an innovative form of interactive art, a completely new way to recreate cultural heritage. The formation of this composition of images, sound and smells is associated with the activation of memory and imagination of both the artist and the viewer. Premonition of the expected and the surprise of discoveries contribute to the pleasure arising from the 3D video mapping and create unique impressions (Fig. 7). The meaningful openness of this interactive artistic work contributes to the formation of the viewer's understanding of the relationships between code systems and signs, providing a methodical education by means of professional art.
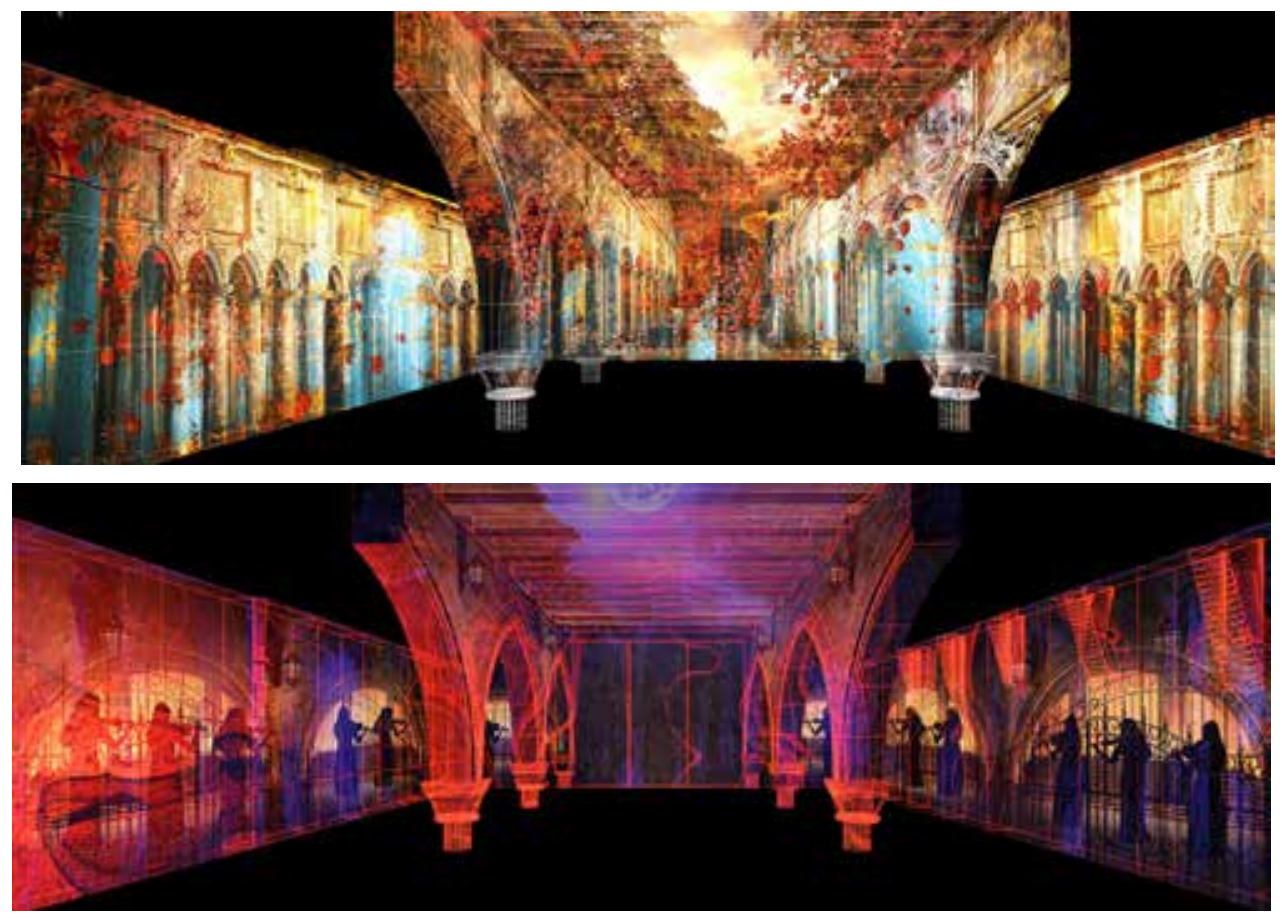

Fig.7. Diocesan Museum of Venice. ${ }^{13}$

Thus, the analysis of the above projects shows that in recent years it has become especially important to study the genesis and dynamics of the development of $3 \mathrm{D}$ video images in the works of artists from various countries, which can be expressed through the following indicators:

- the expressive plasticity of graphic projections;

- a variety of conceptual ideas;

- an innovative character;

- the ability to interpenetrate spaces;

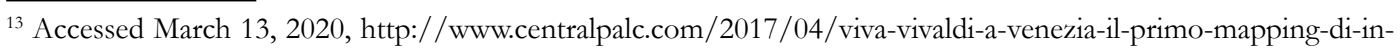
terni-al-mondo/ 
- a strong conceptual idea;

- original ideas about form, space and time.

To fully realise the above tasks professionally, it is necessary to determine the logic of the built museum space, with emphasis on creating images that can display the necessary information in an easily accessible way.

Thus, through interactive artistic images of the architectural environment, socio-cultural reality influences the public consciousness, with 3D video images becoming an important component in the overall composition of the exhibition or museum space, which in turn contributes to updating the cultural and historical content of events and the dissemination and improvement of valuable components of cultural heritage.

Digital art has a huge role in influencing the information of values in modern society. According to the Kryvuts and Gonchar: "...Synthesis of the image of 3D videomapping evolves from the synthesis of sound and images into the synthesis of a new structural model of environmental reflection, which, with the help of multimedia technologies, combines into a single image, document and game" ${ }^{14}$. Multimedia audiovisual tools and technologies have enormous potential in terms of preserving and transmitting cultural heritage. It should be emphasized that the harmonious, holistic combination of multimedia system, in conjunction with professional design solutions for exhibition or museum spaces, is changing the principles according to which exhibitions are perceived, as well as demarking a clear division between author and viewer.

Thus, the development of new methodological approaches to the optimization of media design projects that contribute to the development of multimedia culture and the formation of new criteria for its evaluation becomes relevant. In addition, a characteristic of modern interactive communication systems is that they bring together different cultures and promote mutual understanding between people. Multimedia systems are found in an ever-wider sphere of influence, and this is due to the variety of audiovisual media. Immersive exhibitions directly affect the viewer, changing people's behavior and lifestyle. The phenomenon of interactive systems is such that, by influencing consciousness they form a new worldview and outlook. Digital art, as a communication the culture of today, creates new opportunities for the maximum degree of immersion of the viewer in the interactive world, encouraging him or her to undergo personal experiences. The "social" nature of 3D video images helps to create a new sociotype of person with stable signs of personal perception in modern conditions for the formation of information and cultural space.

\section{References}

BASU, Paul and MACDONALD, Sharon (2007). Introduction: Experiments in Exhibition, Ethnography, Art and Science. In: Paul Basu u. Sharon Macdonald (eds.), Exhibition Experiments. Oxford, Blackwell Publishing.

BENNETT, Tony (2001). Differing Diversities: Transversal study on the theme of cultural policy and cultural diversity. Strasbourg, Council of Europe Publishing.

DEAN, D. (2002). Museum exbibition: Theory and practice. London and New York: Routledge, 1994. Accessed online: https://www.academia.edu/38560181/Museum_Exhibition

GERE, C. (2006). Digital Culture (second edition). London: Reaction books.

${ }^{14}$ KRYVUTS, Svitlana and GONCHAR, Olena. (2019). Polyfunctionality of 3D videomapping ... 
KERLOW, Isaac V. (2009). The Art of 3D Computer Animation and Effects. Wiley. ISBN: 978-0470-08490-8.

KE्SIK, Jacek et al. (2017). An approach to computer-aided reconstruction of museum exhibits. In: Advances in Science and Technology Research Journal, 11(2), p. 87-94.

KESNER, Ladislav. (2000). Muzeum umèni v digitálni době: V nimání obraži a prožitek umèní v soudobé společnosti. Praha: Argo a Národní galerie v Praze.

KRIVUTS, S.V. (2015). The role of media design in the formation of the exhibition space. In: Danilenko (ed.) Bulletin of the Kharkiv State Academy of Design and Arts: Collection of scientific works, V.Ya. Kh.:KSADA, p. 36-41.

KRYVUTS, Svitlana and GONCHAR, Olena. (2019). Polyfunctionality of 3D videomepping as a new structural model of communicative influence in a design environment. In: $A k-$ tuelle Themen im Kontext der Entwicklung der modernen Wissenschaften: der Sammlung wissenschaftli-

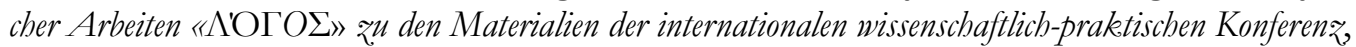
Dresden, 23 Januar, Dresden: NGO «Europäische Wissenschaftsplattform». Vol. 6, p. 17-19. JAGOŠOVÁ, Lucie, KRÁLOVÁ, Jitka (2017). Aktuální kontury profese muzejního pedagoga. Reflexe kvalifikační profilace pracovníků v oblasti muzejní pedagogiky na př́kladu Komise pro práci s veřejností a muzejní pedagogiku AMG ČR. In: Muzeológia a kultúrne dedičstvo, 5(2), p. 141-153.

JAGOŠOVÁ, Lucie, Otakar KIRSCH et al. (2016). Muzejni profese a veréjnost 1. Nástin bistorie a soúăasnosti vzájemných vžtabu muzeí a jejich publika. Brno: Masarykova univerzita. Accessed April 13, 2020, https://archeo-muzeo.phil.muni.cz/media/3056324/muzejni_profese_a_verejnost.pdf

NTALLA, Irida. (2012). Interactivity and audience experience in the modern museum. In E. Kristiansen (ed.), Proceedings of the Dream Conference. Roskilde University, Denmark. ISBN: 978-87-995472-0-3. pp. 252-266.

OUNGRINIS, K.-A., LIAPI, M. and CHRISTOULAKIS, M. et al. (2014). Hybrid Environmental Projection Platform: An interactive educational tool. In: K. Zreik (ed.). Architecture, City and Information Design (EuropIA.14). Paris: Europia, p. 171-184.

SALGADO, M. and JAUHIAINEN, T. \& DIAZ, L. (2009). Re-thinking an Annotation Tool for the Museum Community Generated Content. In: Nordic Design Research Conference (Nordes). Oslo: Nordic Design Research.

SHLYKOVA, Olga. (2004). The Values of Multimedia Culture. In: KnE Engineering 3(8). DOI: 10.18502/keg.v3i8.3624.

ŽUPČÁNOVÁ, Martina and ŽUPČÁN, Ladislav (2014). Kyberpriestor ako moderná forma komunikácie. In: Mediálna seba prezentácia a budovanie individuálneho imiď̌u múzea, v. 21. storočí. Banská Bystrica: Zväz múzeí na Slovensku/Slovenské národné múzeum.

ŻYŁA Kamil, MONTUSIEWICZ Jerzy, SKULIMOWSKI Stanislav and KAYUMOV Rahim (2020). VR technologies as an extension to the museum exhibition: A case study of the Silk Road museums in Samarkand. In: Muzeologia a Kulturne Dedicstvo, 8(4), p. 73-93. 